\title{
МЕХАНІЗМ НАДАННЯ ДЕРЖАВНИХ ТА МІСЦЕВИХ ГАРАНТІЙ ДЛЯ ФІНАНСУВАННЯ ПРОЕКТІВ СТАЛОГО РОЗВИТКУ
}

\begin{abstract}
Проаналізовано міжнародний досвід надання державних та місиевих гарантій підприємствам. Запропоновано механізм фінансування проектів сталого розвитку за програмою державного (місцевого) гарантування на засадах приватно - публічного партнерства, щзо охоплює усі сторони реалізації таких проектів з метою пришвидшення переходу держави до моделі сталого розвитку. Сторонами проекту за такого підходу виступають: підприємство, державні чи місиеві органи влади, держані та комериійні банки. Визначено перспективні напрями реалізації проектів сталого розвитку в рамках реалізації проектів затверджених Стратегію сталого розвитку «Украӥна - 2020».
\end{abstract}

Ключові слова: сталий розвиток економіки, державні гарантії, місцеві гарантії, приватно-публічне партнерство.

Постановка проблеми. На сьогодні екологічна ситуація в Україні та світі вимагає рішучих дій щодо попередження і уникнення нових викликів, що постають перед нами. Перехід країн до моделі сталого розвитку уже давно став першочерговим у всьому світі, оскільки наслідки масового енергоспоживання та безперебійних викидів парникових газів в атмосферу ми уже бачимо. I хоча Україна $\epsilon$ однією 3 країн-підписантів міжнародних угод щодо зміни клімату, процес переходу економіки до сталого розвитку вимагає подолання багатьох проблем та уникнення ряду ризиків. Однак нагальність таких дій є очевидною 3 огляду на стан екологічної ситуації в Україні та світі та зростання вартості викопних видів палива.

В умовах відсутності підгрунтя для проведення ефективної державної політики не мають науково-практичного вирішення окремі проблеми підвищення ефективності використання державних та місцевих гарантій в якості інструменту підтримки сталого розвитку держави та регіону зокрема.

Аналіз останніх досліджень і публікацій. Варто зазначити, що теоретичні основи надання державних гарантій досліджували такі вчені

(C) Мазур Андріана Володимирівна, к.е.н, доцент кафедри фінансів, Національний університет «Львівська політехніка», м. Львів, тел.: 0631929848 , email: andriana.v.mazur@lpnu.ua

Ливдар Марта Василівна, к.е.н, доцент кафедри фінансів, Національний університет «Львівська політехніка», м. Львів, тел.:0979387605, email: marta.v.lyvdar@1pnu.ua

Дідух Оксана Володимирівна, к.е.н, старший викладач кафедри фінансів, oksana.v.didukh@lpnu.ua Національний університет «Львівська політехніка» м. Львів, Україна, тел.: 0322682193, email: oksana.v.didukh@lpnu.ua економісти, як: О.Д. Василик, Л.К. Воронова, В.М. Геєць, О.П. Кириленко, М.I. Корнієнко, В.В. Кравченко, І.О. Луніна, В.М. Опарін, та інші. Проте залишаються малодослідженими питання щодо надання та використання державних гарантій як інструменту для забезпечення фінансування проектів сталого розвитку. Також сюди можемо віднести і те, що немає єдиного Державного реєстру проектів сталого розвитку та проектних пропозицій, який би відповідав за надання державного або місцевого гарантування та за результати їх використання тощо. Вирішення цієї проблематики можливе за умови вивчення та використання міжнародного досвіду надання державних гарантій.

Формулювання цілей статті. Метою статті $\epsilon$ визначення механізму фінансування проектів сталого розвитку за програмою державного або місцевого гарантування та дослідження особливостей міжнародної практики використання інструменту державних гарантій.

Опис основного матеріалу дослідження. Відповідно до ст. 17 Бюджетного кодексу України, державні (місцеві) гарантії надаються за рішенням Кабінету Міністрів України або на підставі міжнародних договорів України виключно у межах і з напрямами, що визначені Законом України «Про державний бюджет» [1]. Отже державне або місцеве гарантування надається державою.

Вважаємо, що використання державного (місцевого) гарантування має насамперед бути спрямоване на стимулювання підприємницької діяльності у певній сфері господарювання в рамках реалізації проектів сталого розвитку, затверджених Стратегію сталого розвитку «Україна-2020» [2] для забезпечення економічного розвитку держави $\mathrm{i}$ регіону загалом. 
Аналізуючи міжнародний досвід надання державних гарантій, бачимо, що в зарубіжних країнах надання гарантій окремим суб'єктам господарювання надаються 3 метою адресного перерозподілу позичкового капіталу з метою фінансової підтримки діючих підприємств, які зазнали труднощів, але мають велике значення для збереження соціальної та економічної стабільності у країні; фінансування (співфінансування) великих стратегічно важливих проектів у сектоpax, які можуть прискорити економічний розвиток (інфраструктура, енергетика, транспорт, телекомунікації, житлове будівництво); розвитку підприємств малого та середнього бізнесу, у т.ч. інноваційних [7, с. 114-127]. Зарубіжні науковці, такі, як М. Фасіо, Р. Маргуліс, Дж. Макконнел зазначають, що державні гарантії під кредити, отримані приватними суб'єктами, надаються для фінансової підтримки діючих підприємств, які зазнали фінансових труднощів, можуть застосовуватися як інструмент державної антикризової політики i як інструмент селективної підтримки окремих підприємств за звичайних умов.

Аналізуючи досвід країн $\mathrm{CC}$, бачимо, що надання державних гарантій поширене й у Європейському Союзі. До основних напрямів їх застосування належать [8]:

- підтримка пріоритетних проектів розвитку держави, виходячи 3 масштабу, галузевої чи територіальної належності;

- розвиток малого та середнього
підприємництва;

- взаємодія в межах державно-приватного партнерства.

У країнах $С С$ діють нормативні правила щодо надання державної допомоги у вигляді гарантій. Такі гарантії можуть надаватися як великим підприємствам, так і фірмам, що працюють у сфері малого та середнього бізнесу. Разом із тим, Європейська комісія розробила низку критеріїв (умов), використовуваних під час прийняття рішеня щодо надання державних гарантій. Однією 3 перших умов $є$ з'ясування фінансового становища позичальника. Необхідна процедура визначена в документі Європейського Союзу "Принципи ЄС щодо надання державної допомоги для відновлення платоспроможності компаній в умовах кризи" [9].

Вважаємо, що на даний час в Україні неможливо забезпечити реалізацію та розвиток пріоритетних напрямів економіки без державної підтримки суб'єктів підприємницької діяльності. Державні (місцеві) гарантії є частиною системи державної підтримки.

Очевидним $\epsilon$ те, що для забезпечення виконання поставлених перед нами завдань та 3 метою покращення екологічної ситуації в Україні та світі загалом нова Енергетична стратегія та Стратегія низьковуглецевого розвитку повинні базуватись зокрема i на розвитку таких напрямів, як окреслення відповідальності за екологічний стан держави, окремого регіону, населеного пункту, приватного виробництва тощо у контексті публічноприватного партнерства. 3 огляду на участь України у міжнародних угодах щодо зміни клімату та ратифікації Паризького договору сторін рамковової конвенції ООН зі зміни клімату затверджено Стратегію сталого розвитку «Україна - 2020». Зокрема, у плані дій щодо впровадження положень Стратегії розроблено вектори руху реалізації реформ та програм розвитку держави, серед яких Програма розвитку малого та середнього бізнесу, реформа фінансового сектору, Програма збереження навколишнього природного середовища та інші.

Перехід України до моделі сталого розвитку економіки передбачає здійснення комплексу обгрунтованих та виважених управлінських рішень щодо побудови національної екологічної стратегії. В першу чергу, необхідним є вживання заходів щодо покращення екологічної ситуації в країні та виконання покладених на нас зобов'язань міжнародним співтовариством в рамках Кіотського протоколу та прийдешнім введенням в дію Паризької угоди. Такі заходи повинні передбачати активізацію процесу переходу країни до використання відновлювальних джерел енергії. Важливим $\epsilon$ переорієнтація країни 3 сировинно-орієнтованої до інноваційної економіки та відмова від займаної пасивної позиції, коли викиди парникових газів скорочуються не з огляду здійснюваних заходів по їх зниженню, а в силу обставин, що склалися. Іншим важливим питанням $\epsilon$ налагодження дієвого механізму банківського кредитування 3 метою реалізації концепції сталого розвитку економіки шляхом, який грунтувався б на засадах державного та місцевого гарантування. Лише така політика сприятиме ефективному економічному та природному відтворенню країни та налагодженню співпраці 3 міжнародним співтовариством.

Розроблення проектів сталого розвитку на засадах приватно-публічного партнерства забезпечить зростання ефективності їх реалізації. Налагодження такого роду співпраці потребує законодавчо врегулюваного механізму, який би передбачав умови та критерії до розроблення проектів сталого розвитку.

Механізм фінансування проектів сталого розвитку повинен об'єднувати усі сторони 
реалізації таких проектів з метою пришвидшення переходу держави до моделі сталого розвитку.

Однією зі сторін реалізації проектів сталого розвитку у рамках пропонованої програми виступають підприємства, які розробляють проект, передбачений Стратегією сталого розвитку «Україна- 2020» та державною стратегією регіонального розвитку на період до 2020. Таким чином, необхідним є розроблення нормативної документації для підприємств щодо реалізації проектів сталого розвитку для подання заявки на кредитування за умовами програми надання державних та місцевих гарантій для фінансування зазначених проектів банківським сектором, 3 метою гармонізації основних пропонованих вимог щодо фінансування процесів сталого розвитку 3 міжнародним законодавством, зокрема Директивою Європейського Парламенту та Ради 2014/95 / ЄС.

Другою стороною механізму фінансування проектів сталого розвитку виступатимуть державні та комерційні банки в частині надання кредитів під проекти сталого розвитку в рамках програми надання державних та місцевих гарантій для фінансування проектів сталого розвитку банківським сектором. Відповідно до цього, важливим $є$ виокремлення підходу для банків щодо відбору проектів сталого розвитку для надання кредитів в рамках програми.

I третьою стороною механізму фінансування проектів сталого розвитку виступатимуть державні та місцеві органи влади в частині надання державних та місцевих гарантій під надання кредитів державними та комерційними банками для реалізації підприємствами проектів сталого розвитку.

Таким чином, запропоноване тристоронне приватно-публічне співробітництво щодо розроблення та реалізації проектів сталого розвитку забезпечить максимальну відповідальність сторін щодо відповідності проекту критеріям відбору для участі у програмі та прозорості щодо прийняття рішення про надання державної підтримки для реалізації проектів сталого розвитку. 3 іншої сторони, запропонований механізм передбачає фінансування проектів, які успішно пройшли відбір за усіма критеріями, 3 залученням державної або місцевої підтримки.

Ще одним важливим моментом при налагодженні дієвого механізму фінансування проектів сталого розвитку за програмою державного або місцевого гарантування $\epsilon$ необхідність формування Державного реєстру проектів сталого розвитку та проектних пропозицій.

Впровадження та реалізація пропонованих заходів забепезпечить досягнення ключових показників та стратегічних індикаторів, що оцінюють хід виконання реформ та програм, передбачених Стратегію сталого розвитку «Україна - 2020». Окрім цього, пропоновані рекомендації дадуть можливість чітко визначити механізм фінансування проектів сталого розвитку банківським сектором у контексті розроблених Стратегією зон відповідальності влади, бізнесу та громадянського суспільства.

Висновки та перспективи подальших досліджень. У результаті проведеного дослідження визначено перспективні напрями реалізації проектів сталого розвитку:

1. розроблення програми надання державних та місцевих гарантій для фінансування проектів сталого розвитку банківським сектором, яка б передбачала державне та місцеве гарантування надання державними та комерційними банками кредитів для реалізації підприємствами проектів сталого розвитку;

2. розроблення нормативно врегульованого порядку відбору проектів сталого розвитку, для реалізації яких надається державна або місцева підтримка;

3. визначення механізмів державної та місцевої підтримки в рамках програми надання державних та місцевих гарантій для фінансування проектів сталого розвитку банківським сектором.

Перспективами подальших досліджень щодо зазначеного напрямку реалізації проектів сталого розвитку $\epsilon$ ідентифікування концептуального підходу для банків щодо відбору такого роду проектів для надання кредитів в рамках програми надання державних та місцевих гарантій для фінансування проектів сталого розвитку банківським сектором.

\section{ПЕРЕЛІК ВИКОРИСТАНИХ ДЖЕРЕЛ}

1. Бюджетний кодекс України [Електронний ресурс] із змінами і доповненнями: затверджений Законом України № 2456-VI від 08.07.2010 p. - Режим доступу: http://zakon3.rada.gov.ua/laws/show/2456-17

2. Стратегія сталого розвитку «Україна - 2020»: Указ Президента України від 12.01.2015 № 5/2015 //Урядовий кур'єр. - 2015. - №6.

3. Про затвердження Державної стратегії регіонального розвитку на період до 2020 року: Постанова Кабінету Міністрів України від 06.08.2014р. №385 // Урядовий кур’єр. - 2014. - №160

4. Directive 2014/95/EU «On disclosure of non-financial and diversity information». - Access: http://eurlex.europa.eu/legal-content/EN/TXT/?uri=CELEX:32014L0095 
5. Kyoto Protocol // The United Nations Framework Conventionon Climate Change. - Access mode: http://unfccc.int/kyoto_protocol/items/3145.php.

6. Текст Рішення 21-ої Конференції Сторін та Паризької Угоди / Conference of the Parties Twenty-first session Paris, 30 November to 11 December 2015. Durban Platform for Enhanced Action (decision 1/CP.17) Adoption of a protocol, another legal instrument, or an agreed outcome with legal force under the Convention applicable to all Parties. [Електронний ресурс]. - Режим доступу: http://unfccc.int/resource/docs/2015/cop21/eng/109r01.pdf.।.

7. Карапетян О.М. Міжнародний досвід надання державних гарантій підприємствам: сучасні детермінанти та вплив на фінансову безпеку держави /. О.М. Карапетян // Сучасні підходи до управління підприємством: збірник наукових праць національного технічного університету України «Київський політехнічний інститут». К.: 2016. - №1. - С. 114-127.

8. Лютий I. О. Регулювання надання державних гарантій в Україні / I. О. Лютий, О. С. Лондар // ФінансиУкраїни. - 2016. - № 2. - С. 28-48. - Режим доступу: http://nbuv.gov.ua/UJRN/Fu_2016_2_4.

9. Communication from the commission community guidelines on state aid for rescuing and restructuring fi rms in diffi culty // Official Journal of the European Union. - C 244/2. Access mode: http://eur-lex.europa.eu/legal-content/ EN/ALL/?uri=CELEX:52004XC1001(01).

\section{REFERENCES}

1. Budget Code of Ukraine (n.d.). zakon3.rada.gov.ua. Retrieved from http://zakon3.rada.gov.ua/laws/show/245617 [in Ukrainian].

2. Stratehiia staloho rozvytku "Ukraina - 2020" [Sustainable Development Strategy "Ukraine-2020"] Decree of the President of Ukraine No. 5/2015, 12.01.2015. Uriadovyi kurier. - 2015. - No.6 [in Ukrainian].

3. Pro zatverdzhennia Derzavnoii stratehii rehionalnoho rozvytku na period do 2020 [On Approval of the State Strategy for Regional Development for the period up to 2020] Resolution of the Cabinet of Ministers of Ukraine No. 385, 06.08.2014. Uriadovyi kurier. - 2014. - No. 160 [in Ukrainian].

4. Directive 2014/95/EU «On disclosure of non-financial and diversity information». - Retrieved from: http://eurlex.europa.eu/legal-content/EN/TXT/?uri=CELEX:32014L0095

5. Kyoto Protocol The United Nations Framework Conventionon Climate Change. - Retrieved from: http://unfccc.int/kyoto_protocol/items/3145.php.

6. Conference of the Parties Twenty-first session Paris, 30 November to 11 December 2015. Durban Platform for Enhanced Action (decision 1/CP.17) Adoption of a protocol, another legal instrument, or an agreed outcome with legal force under the Convention applicable to all Parties. Retrieved from: http://unfccc.int/resource/docs/2015/cop21/eng/109r01.pdf.।.

7. Karapetian, O. (2016) Mizhnarodnyi dosvid nadannia derzhavnyh harantii pidpryiemstvam: suchasni determinant ta vplyv na finansovu bezpeku derzhavy [International experience in providing state guarantees to enterprises: current determinants and influence on state financial security] Suchasni pidhody do upravlinnia pidpryiemstvom: zbirnyk naukovyh prac Nacionalnoho tehnichnoho universytetu Ukraiinu "Kyivskyi politehnichnyi instytut" - Modern approaches to enterprise management: a collection of scientific works of the National Technical University of Ukraine "Kyiv Polytechnic Institute", №1, P. 114-127 [in Ukrainian].

8. Liutyi, I. \& Londar, O. (2016) Rehuliuvannia nadannia derzhavnyh harantii v Ukraini [Regulation of the provision of state guarantees in Ukraine] Finansy Ukrainy - Finance of Ukraine, № 2, P. 28-48. - Retrieved from: http://nbuv.gov.ua/UJRN/Fu_2016_2_4 [in Ukrainian].

9. Communication from the commission community guidelines on state aid for rescuing and restructuring firms in difficulty Official Journal of the European Union, Art. 244/2. Retrieved from: http://eur-lex.europa.eu/legal-content/ EN/ALL/?uri=CELEX:52004XC1001(01).

Одержано 15.03.2018 p. 